\title{
Description of the Concept of "Vahdatu L Vujud" in the Poetry of Ravshan-Poets
}

\author{
Professor A. M. Mannonov \\ Tashkent State University of Oriental Studies \\ Doctor of philological sciences
}

\begin{abstract}
The article examines the contribution of Boyazid Ansari, the founder of the Sufi movement in Afghanistan, to the development of Sufi teachings and Pashto literature. Through the mystical-philosophical-religious views of Boyazid Ansari, an attempt is made to reveal the essence of the concept of "Vahdatu l vujud". It is noted that Boyazid Ansari was the founder of the Ravshaniya doctrine, which expressed his views in a prosaic way in Pashto. In Afghanistan, Ansari's contemporaries and poets of later times established a new literary process, describing themselves as his spiritual followers, describing the Ravshani doctrine.
\end{abstract}

Keywords: Sufism, Ravshani, Boyazid Ansari, Islam, philosophical mystical views, Prophet, Qur'an, Pir, Muslim, Believer, philosophical-pantheistic view, Sufi, divine, Vahdatu 1 vujud, sacred knowledge.

\section{Introduction:}

The Ravshani school of Sufism [1] is a movement that emerged in Afghanistan in the 16th century and was founded by Boyazid Ansari. Boyazid Ansari was born in 1525 in the city of Jalal-Abad (Punjab) in Afghanistan. Among Uzbeks he was known as Bobo Ravshan. His ancestors were famous religious scholars. Boyazid Ansari's supporters gave him the title of Piri Ravshan. Ansari's works include The Condition of the Helper Pir and The Purposes of the Believers, especially his Khayru 1 Bayan [2], which sets out his main religious-mystical-pantheistic views. Ansari's works are written in Pashto, Persian and Arabic. Ansari suggested his own alphabet for Pashto.

Much scientific work and analytical articles have been done on the teachings of Sufism in the West and the East. Different views have been expressed on this religious-mystical doctrine. Well-known philosophers, historians and orientalists of the world have written many works on this subject and expressed their views.

On the doctrine of Sufism Eskerkhanov G.L. "Sufism is a mystical and philosophical doctrine in Islam, which promotes the intuitive knowledge of Allah, and its goal is to find and attain the absolute the truth without any logical observation." [3]

According to Mamatov M.A, head of the department of national ideas and ideology at Fergana State University, Sufism is a cosmopolitan phenomenon for many reasons, including various national cultures and national ideas of the peoples of the Middle East. The main source of Sufism is the Holy Qur'an. There is no doubt that the hadiths of the Prophet Muhammad (peace and blessings of Allah be upon him) are also a source of inspiration for Sufism.

Sufism is a religious-philosophical doctrine characterized by its complexity, contradictions and diversity of sources and social bases." According to the author, Sufism is completely alien to religious extremism, Islamic fundamentalism and condemns it.

"Sufism," writes Mamatov M.A, plays an important role in the history of the Eastern Muslim spiritual world. The research work of Islamic scholars, historians, philosophers and other social sciences reveals the roots of this pantheistic current in Islam, its place in the spiritual and social development of the Muslim world, the nature of contradictions in socio-political issues and the history of almost 14 centuries. allows us to understand the stages of evolutionary formation." [4]

What features of the Ravshani doctrine that emerged in Afghanistan in the middle of the 16th century and in what aspects it is noteworthy is important for the science of oriental studies. This article deals with the philosophical mystical-pantheistic views of Sufism in the works of Ravshan poets, romantic imagery, its sources, methods of expression, how the attitude to the Truth, man, society, social issues are expressed, the essence of the priorities of Ravshaniya's teachings was analyzed. 
At the heart of this article is the view that this doctrine, initiated by Boyazid Ansari in Afghanistan, embodies the mentality of the people of the country, the Islamic beliefs, and is a Poetic-Sufi path based on it.

The article is based on the analytical method of research.

The significance of the article is that the works of poets and writers who wrote in Pashtun, as well as the fact that the field has not been fully explored, show that much scientific work still needs to be done in this regard.

\subsection{History of Sufism: - The main sources of Sufism, its social significance and reasons for its spread}

Sufism is a doctrine that began in Muslim countries about 1,200 years ago and spread throughout the Middle East, from North-West Africa to China and Indonesia.

As for the lexical meaning of the word "Sufi", it is obvious that it has different interpretations. Abu Rayhan alBeruniy, one of the leading scholars of the East, states that the word Sufi is derived from the Greek word for "wise." [5]

According to the scholar and philosopher Ahmadi Jam, the word means "sofa, that is, those who sit on the couch." [6]

Shaikh 'Ali ibn Shaikh' 'Uthman al-Jullabi al-Hujrawi commented on the word Sufi in his book Kashf ul Mahjub: Sufis are those who wear a garment made of wool and call those who follow them; sometimes people with pure hearts, good intentions, sincere, wise people were called Sufis. Some scholars say that Sufism is derived from the meaning of "Safa, purity." Sheikh al-Jullabi remains of the opinion that the word Sufi is derived from the word "pure." [7]

Many Islamic scholars translate the word Sufi into Arabic as "Tasawwafa," meaning to wear a garment made of coarse wool. Hence, it is argued that a Sufi means a person who lives a Sufi.

Western Islamic scholars viewed Sufism as a mystical-pantheistic view of Islam that preceded other religions that existed before it. F.A. Toluk was one of the first to say that Sufism was a pantheistic method derived from Zoroastrian priests. He later rejected this view, arguing that Sufism was specific to Islam and emerged in the early days of Islam. [8]

R. Dozi described Sufism as a philosophical doctrine that arose as a result of the Iranian protests against the Arab invasion. [9]

Richard Hartmann and Max Hartenn viewed Sufism as a method that introduced Islam to Buddhism and the early Vedas. [10]

Commenting on the social origins of Sufism, the orientalist A. Krimsky said: "There are two currents in it: one is the western current, which began with the Prophet Muhammad Mustafa; the other is the Indo-Persian eastern current; He argued that while there was a Christian influence in the first stream, there was a Buddhist influence in the second stream. [11]

Initially, Sufism was formed within the framework of ascetic ideas, but later it passed to the Muslim dervishes and became a large-scale religious-philosophical doctrine. Gradually it split into several directions and sects.

In his work on Sufism, E.E. Bertels writes, "When we express an opinion about this or that trend, we still go into abstraction, we can only imagine the real picture." The characteristics of Sufism are as follows: He writes: "To understand Allah as the only true being (Vahdatu 1 vujud), to attach infinite love to him, to believe in the meaning of one's life as the Truth, to follow the difficult and arduous path of life in order to attain Allah's pleasure. to pass, to see his power and greatness through the "eye of the heart," and to be able to feel it through the senses. This theory of divine knowledge of "sacred knowledge" is realized through mystical-mystical knowledge, and gradually returns to God Himself. In this way, Sufis reach the perfection of emotional knowledge, they do not make logical decisions on their own, they adhere to strict collective discipline.

The approaches of Sufis to these organizational systemic issues are not the same, so there are differences of opinion on the basis of them. There are problems in drawing clear conclusions about the nature, role, and significance of Sufism. 
Ahmadi Jam expressed ideas that clearly explain the essence of Sufism, including: "A Sufi needs three things free hands, a free heart, and a free body; abstinence from worldly interests, abstinence from greedy pleasures, abstinence from heart (abstinence from sex).

Sufism later developed a pantheistic philosophy in Central Asia, Iran, and India. in the second (the oneness of being), the idea that "Allah is the universe" is the main determinant.

The adherents of "Vahdatu 1 vujud" are interpreted to believe that there is only one God. It is believed that all beings in the universe came into being by the command of the Creator, are governed by His will, and that in all the mysteries of existence, from the smallest to the largest, the sole Ruler is the power of the Almighty.

Proponents of Vahdat al-Varwa, on the other hand, have a slightly different view of existence, that is, they view life as a blessing bestowed on man in this world, and that God has given man this blessing and has made man his ruler. [12]

Because of these views, Muslim scholars consider the "Vahdatu 1 var" movement and its teachings to be harmful and dangerous for Islam.

There are conflicting views on whether Sufi philosophy is in line with the tenets of Islamic law. Dervishes, pirs, and their murids, who have been persecuted for centuries for their Sufi views, are common. For example, it is known that Mansur Hallaj was persecuted and executed by the priests of the time for the idea of "Ana 1 haqq".

In poetry, the tendency towards the romantic works of representatives of Sufi poetry is expressed as aspects of the manifestation of inspiration. E.E. Bertels emphasizes that the philosophical system developed in the symbols of Baba Kuhi, Ahmadi Jam, Abdul Qadir Gilani was continued in the works of later philosophers Ibn al-Arabi, Sadru d Din Qunawi [13].

There is a difference between the Sharia and the teachings on the approach to the pillars of Islam. Sectarians differ slightly in their approach to the rules set by the Sharia's regarding the treatment of the halal and the haram. The views of the sectarians on prayer and fasting are also different from the requirements of the Sharia.

In Sufism, there are currents that serve the right stream - orthodox Sufism feudal - system, and the left stream - in opposition to the feudal system, and on this basis are considered atheist currents. Among the representatives of the left are cultural figures, representatives of folk art, writers and poets of humanistic poetry.

\subsection{Attitudes of Ravshani poets to the main idea of the doctrine of "Vahdatu I vujud" in Afghanistan in the XVI century}

Ravshan poetry is a poetry that originated in Afghanistan in the 16th and 17th centuries and is imbued with the philosophical and Sufi ideas of Boyazid Ansari. In this poem, the idea of "Vahdatu 1 vujud" (unity of the being) is central. It involves the interpretation of complex philosophical-theological, religious-moral, socio-ethical norms in the interpretation of Piri Ravshan. This concept and related themes and descriptions later took center stage in the works of a number of Ravshan writers, including Arzani, Mirza khan Ansari, Wasil, Ali Muhammad Muwli, Davlat Lavanay, Karimdod, etc. Boyazid Ansari stated in his work "Khayru 1 bayan" his ideas are closely connected with his ideas on the organization of society. However, it was not a blind follow-up or imitation, but a creative development of his creative product and its presentation to the public in a more colorful way. Compared to the teachings of Boyazid Ansari, it is fair to say that the work of these poets is somewhat broader and more diverse. His contemporaries and poets of the next generation, inspired by Boyazid's ideas, polished his views aesthetically and used new unique means of art. In doing so, they sought new ways of expression and worked to create new Sufipantheistic images, symbols, and descriptions.

In their search for means of imagery, the poets turned to the traditions of universal Persian Sufism. Persian Sufi poetry, which flourished before the emergence of enlightened literature, had a great and rich experience in reflecting philosophical views, forming images of the mystical-enlightened world, metaphorical and symbolic expression of the variety and associativity of descriptions in interpreting the themes of Sufi philosophy.

Using the experience of Persian-language Sufi poetry, the poets of the Ravshani movement enriched the concept of "Unity of Being" with a variety of additional component descriptions, artistic means. These additions contributed to a fuller understanding of the teachings of Boyazid Ansari. 
In general, this poetry was a union, a rounding of the two beginnings. The first basis was the prose of Boyazid Ansari, and the second was examples of poetry based on the rich Sufi traditions of the Persian language.

The union of the two beginnings had an impact on the interpretation of the Ansari doctrine, of course, and two levels of poetic thought: the first - doctrinal metaphysics; the second was reflected in the expression of romantic themes.

These two directions did not struggle to gain an advantage over each other, but worked closely together in the area of more efficient use of mutual means. This was not accidental, for it was important for the Ravshan poets to explain and justify the idea and doctrine of "Vahdatu 1 vujud" to the people. To this end, they resorted to the "open text" method, although Mirzakhan, Davlat, Vasil, Karimdod were each skilled poet in the use of complex symbolicallegorical and metaphorical images of Sufi lyricism.

By Ravshan poets, we mean about thirty poets who, following the ideas of Boyazid Ansari, created in order to convey the teachings of Ansari to the Pashtun people and other peoples and tribes. As mentioned above, the most famous of them were Arzai, Mirzakhan Ansari, Ali Muhammad Muhlis, Vasil Rushani, Davlat Lavanay, Karimdod Rushani.

Although this is not a collection about the life and work of the poets, it is clear from the poetic legacy they left that the poetry of the Ravshani poets was directly influenced by Indian (Pakistani) literature, Iranian literature. For example, a poem by Mirzakhan describes his impressions of the Dean's battle and the details of the annual Holi holiday, which is widely celebrated in India. State Lavanay has written several short poems about his origins. Davlat Lavanay and Khushkholkhan Khattak wrote works about the personality, origin and genealogy of Boyazid Ansari. Davlat Lavanay cites about 20 of Ansari's ancestors in his work. Boyazid's life and work are described in detail in Mukhlis's Holnoma. In Vasil and Davlat's poems, social issues related to rural life and agriculture are raised. The difficulties and problematic questions of Pashtun farmers who migrated to India on how to adapt to those new places were raised. The emigrant Pashtun peasants not only followed the laws of India but also maintained their own Pashtun system and established rules of coexistence with the local Indian population.

In one of his works, Mirzakhan focuses on women's issues. He writes verses of social significance, describing in detail the subject of the honor of Muslim women.

Although the poetry of the enlightened poets is mainly focused on the comprehensive coverage of mysticalphilosophical teachings, it is clear that in some poems the issues of national characteristics have not been neglected.

In their thoughts on the nature and purpose of poetry, the poets explained to the people in a Sufi way that poetry is a product of divine inspiration, a means of knowing the Truth. They stated that their main tasks were to praise Allah through poetry, to give religious and enlightened Pandu advice to the common Pashtun peasants, and to guide them. Although the poets imitated the ways and methods of Persian literature, their systems in the use of poetic means, they used them to create their own national methods and motives. Although Vasil enriched his work with folklore, he contrasted it with it in content. In the poems of the state, the emerging sense of patriotism of the national consciousness rose to the forefront.

Pelevin M.S, in his scholarly work, Afghan Literature in the First Half and the Middle of the Seventeenth Century, Ravshani's poetry is richer in form and content than the poetry of later poets, the forms became an easy way to reach the minds of the illiterate Pashtun peasants and herdsmen.

The following is the attitude of the representatives of the teachings of Ravshani to such concepts as Allah, Man, Prophet, Heart, Fano, Baqo.

These verses in the works of the poet Mukhlis can serve as an epigraph of the Ravshan doctrine:

"If there is no God in everything, then it is not something,

If there is no God in everything, then there is no God." [15]

If this phrase is considered as the main idea in the Sufi-pantheistic poetry of the Ravshani, the content of this poetry seems to be clarified. The main focus of the creators is to interpret this thesis, to reveal its meaning. The poets, based on the ontological and epistemological instructions of the Qur'an and the hadiths, observed within the concept of 
"Oneness", including the pantheistic description of the monotheistic phrase "there is no god but Allah" as "there is nothing but Allah." Moreover, the Qur'anic meaning of Allah's closeness to Man was understood by the enlightened poets as a subtle meaning, and they treated it with dignity. They introduced symbolic signs and clarifications that gave new names to Allah's beautiful names, namely Asmou 1 husna. Poets consider the phenomenon of Allah to be the greatest and infinite (Being) and a Being that is beyond the scope of human thought, which does not fit into the dimensions of any space or time.

As the enlightened poets continue the ideas of Boyazid Ansari, they treat Allah as the only, macro-universal Being. Allah is the main force that moves the being, gives life to all beings in the universe, from the smallest particle to the largest creatures, and Allah Himself is invisible and does not need anyone or anything, never, under any circumstances. He exists in the fact that everything exists, and his existence (hasti) never disappears, does not pass from one quality to another, from one essence to another, they believe that he is eternally unique in his Essence.

Observing the evolutionary continuation of the views of the rabbis, it is clear that they first realized that the phenomenon of Allah was secret, invisible, miraculous, mysterious, powerful, unspecified, like a treasure trove, yet possessing the potential to create the Universe. When self-interest arises in Allah, he decides to show his greatness, power, sertarannum, and beauty.

The rabbis interpret this phenomenon as an example of the image of a "seed" and contrast its secrecy with the appearance of a "tree". They also interpret the image of "water" and "ocean" as "drops", "rain", "hail" and so on.

They believe and propagate the nature of creativity, which is unique to God and that He has power within everything created. This process is constant, and the power of Allah is the infinite source, the foundation, the core, the beginning of the beginnings. This motif is the main, central fiber in both the religious poetry and the romantic lyrics of the Ravshani.

In carrying out the teachings of Vahdatu 1 vujud, the poet Ravshan and their successors attach great importance to the bond between Allah and man. They emphasize that the unity of Allah and man cannot be equated with the unity of Allah and other beings. The rabbis state with confidence that all that exists on earth and in the heavens belongs to Allah, that Allah encompasses everything and can be everywhere. However, his unity with Man is very important, because man is respected among the creatures because man has been endowed with the blessing of consciousness. It is for this reason that man has a responsibility to realize his individuality and the power and unity of God. The Ravshani expressed the creation of man in various Sufi variants and details. It is interpreted that man did not exist in the mysteries of God until he was created in the image of Adam, until he was commanded to create him. God created man as a worshiping, thankful servant. One of the themes emphasized in Ravshani's teaching is that they believe that the unity of God and man existed before the creation of man.

The image of the Prophet Muhammad Mustafa was an important aspect of the enlightenment that revealed the unity of God and man. The Sufis approached the phenomenon of the Prophet Muhammad (S.A.W.S) in a mysticalphilosophical sense rather than in a traditional-canonical sense, in accordance with the emanation interpretation of the concept of "Vahdatu 1 vujud". According to Boyazid Ansari, the soul of the Prophet Muhammad was first created before the creation of the worlds, and it was in the form of light, and then from this light were created "special spirits" [16], perfect souls (prophets, dervishes, guardians, elders) and even Adam. Muhammad Mustafa was born as the "end of the prophets", that is, the prophet of the end times, but in fact he is the expression of the power of Allah, the divine companion of all discoveries and innovations. The founders and adherents of the enlightened doctrine philosophically observe this idea within the letters "Alif", "Mim" and use the names "Ahad", "Ahmad", "Nur" symbolically. Nurnoma is a treatise on these ideas that has been read by ordinary Muslims for many years. [17]

In the literature of Muslim nations, in the teachings of Islamic law and teachings, the theme of the human heart has always been in the spotlight. In the teachings of the rabbis, too, the question of the heart is given sufficient importance. The enlightened poets liken the soul to a mysterious castle containing the divine essence. In one of the hadiths, Allah says (interpretation of the meaning): "I am neither in the heavens nor on the earth, but I am in the heart of my sincere servant." According to the representatives and followers of the teachings of Ravshaniya, the sincere heart of a person who is cleansed of various impurities and worldly sins is a place for the mercy of Allah. 
This feature does not change its essence as long as humanity lives. They describe the human heart as the house of God's love, the spring of Kawthar. An example of this spring is a mirror, which reflects the beauty of the Truth, the Earth. When a person is able to look at the world through the eyes of the heart, he realizes that the world is a beacon of God's power. The heart is the inner side of the precious ore, and to hurt it, to hurt the human heart, is tantamount to destroying the Ka'ba.

Representatives of the teachings of Ravshaniya believe that the process of "Vahdatu 1 vujud" is carried out directly through a pure heart. The ignorant, on the other hand, live in ignorance of the existence of God in everyone's heart. The enlightening aspect of this doctrine was to explain to the people of the time the importance of binding the heart to God. According to this teaching, when a person's heart is not in contact with the Creator, his heart becomes a battleground between the Most Gracious and Satan, and he lies in confusion. Man's duty is not to give in to Satan, not to allow him to enter into himself, into his own heart.

In order to protect his heart from the accursed Satan, a Muslim must constantly remember Allah.

As a result of hard work, Piri, with the perfect protection and support of Piri, cleanses his soul from greed, from the tricks of the deceitful devil, and gives his heart to the Creator alone, leading man to the status of Fano in the eyes of poets.

In the state of Fano, if a person realizes that he is living in a mortal world, then when this mortal life is over, he will enter the world of Baqo. The transition to eternal status means that when a person's life is over, his soul will move to the eternal world and return to the presence of the Creator.

For this reason, the poets of the Enlightenment call man to renounce his "I", to put aside his empirical and physical, individual desires, to sink into the state of Eternity, and to connect his soul to the Almighty. They propagate the taste of attachment to Allah by dying greedily before physical death. It is described as the goal of Sufism to burn in the work of Allah and then return to its original state of purity, embodying the love of the Truth. In this way, eternal life is found in the sight of Allah, Piri Ravshan explains.

\subsection{The socio-political situation in Afghanistan in the XVI-XVII centuries and the role of Ravshan poets in it}

In the middle of the 16th and 17th centuries, Afghanistan became a battleground between the Babur's and the Safavids.

Descendants of King Babur, known as the Great Mongols, ruled in the direction of Kabul, Afghanistan. Kabul is a strategically important part of the road between Central Asia and India.

The Safavids were mainly kings from the Safavids dynasty of Iran, who ruled in and around the strategically important city of Kandahar on its way from Iran to India.

After consulting on the intentions of foreign rulers to occupy Afghan lands and carry out bloodshed there, Afghan tribal leaders united in the fight against foreign invaders for the freedom and liberty of their lands. [18]

Boyazid Ansari and his supporters took the lead in the fight against foreign invaders in Afghanistan. They joined the national liberation struggle in order to unite their Pashtun and Afghan tribes and cleanse their homeland of foreigners. As a result, in the 18th century, the kingdom of the Abdali tribes was established in Herat and the kingdom of Gilzai in Kandahar. [19]

It was not in accordance with orthodox Islamic law that the representatives of poetry, based on the Sufiphilosophical teachings of Boyazid Ansari, understood the world as an indivisible, closely related divine being. While Muslim Orthodox scholars unequivocally adhere to the Sharia beliefs about the Hereafter, the Hereafter, the Day of Judgment, Paradise, and Hell, the followers of the sect say that all human beings, regardless of religion, nationality, or race, are equal before God alone because they are created by a single divine power. they were approaching.

Criticizing the leaders of the Sharia, the enlightened poets and their followers divided people into "Al-Khas" (the highest class, i.e. sayyids) and "Al-A'am" (common, i.e. blacks).

Noble, high-spirited, goal-oriented, wise, perfect, and those who know the Truth are respected as wise, Piri teachers as Special People. Such people were called "the stars of the day" and "the pearls of God." 
Mullahs, muhtasibs, preachers, preachers, preachers, and false sheikhs were in fact criticized as ignorant of the love of the Truth. In condemning them, they created negative images such as hypocrites, hypocrites, arrogant, thieves, and possessors of dead souls. Such satirical images are common in their creations.

In the works of enlightened poets, the concept of "unity" exists in the context of socio-ethical norms. The radical wing of Sufism is not unfamiliar with social issues, as they criticize the current system, those in power and defend the idea of human equality.

In the works of Arzoi and Karimdod, there were relatively few social outbursts. In Vasil's works, the shortcomings of society are strongly condemned, and the sources of these shortcomings are sought. Vasil believed that the cause of human shortcomings was in the relationship of lust and goodness in him. The poet opposed violence and aggression. In the works of Mirzakhan, Mukhlis and Davlat, the issue of the unity of Allah and man is considered a socially important issue.

The theme of poverty is interpreted differently in the works of poets. The enlightened creators condemned negative desires such as wealth, luxury living, and greed for the world as trivial things. They said that love for Allah alone is eternal. According to them, the greatest happiness and wealth for man is to attain the Truth through this poor life. According to them, "Dervishes are kings of faith", "Rich people are actually poor people".

In their poems, the poets criticized satirical imagery, such as deception, extortion, corruption, and greed, which had become a war against injustice, inequality, injustice, betrayal, oppression, aggression, and violence in social and political life. They created with the belief that the wrongdoers will inevitably be punished by Allah. The ideas of national liberation in the works of Ravshan poets were examples of poetry that emerged as an inspiring food for the Pashtun and Afghan people in the national struggle.

\section{III -Conclusion}

In the middle of the 16th and 17th centuries, due to the influence of Islamic religious and philosophical ideas in Afghanistan, the Ravshani doctrine was founded by Boyazid Ansari. The reason for calling this movement the Ravshani doctrine was that of Baba Ravshan, Boyazid Ansari (1525-1572), respected as Piri Ravshan. Sufi mystical pantheistic views were the basis. Boyazid Ansari and his followers led the Pashtun peasants in the national liberation struggle for the liberation of Afghanistan against the policies of local rulers and Babur's. The Ravshaniya movement was suppressed in the 1930s. Arzoi, Davlat Lavanay, Mirzakhan Ansari, Mukhlis, Vasil Ravshani and others, who were well-known poets of their time, supported the teachings of Ansari. The works of the poets created a new era in Pashto literature in Afghanistan.

Boyazid Ansari's teachings are considered to be a Pashto interpretation of Sufism. Ansari created simple prose and poetic examples that were understandable to the Pashtun people. Poems and ghazels, which were the product of the work of enlightened poets, emerged as examples of fiction in the Pashto language.

The creation of Sufi-philosophical images, symbols, new descriptions ensured the attractiveness of this poetry.

The main phrase in the philosophical approach of the poets "Vahdatu 1 vujud":

They supplemented the word "there is no god but Allah" with their pantheistic ideas and created a doctrine based on the idea that "there is nothing but Allah."

"If there is no God in anything,

Then it is nothing.

There is no God in anything,

So it's not there. "

This Philosophical-Sufi idea was enriched and enriched by the proponents of the Ravshani movement from work to work, line by line. They used the methods of Arabic-Iranian poetry and created new weights, new images, epithets, metaphors, symbols, forms and meanings on the basis of these methods.

Poets such as Boyazid Ansari, Mirzakhan, Wasil, Davlat, Karimdod, Khushkholkhan Khattak, who approached the Sufis on the basis of the ontological and epistemological rules and rulings of the Qur'an and hadiths, took a historical place in the national liberation struggle of the Pashtun people in Afghanistan. 
Proponents of this doctrine, who fought for the ideas of social justice and equality in social life, considered poetry as the main tool in achieving their dreams. They fought against negative stereotypes in society such as aggression, robbery, lying, hypocrisy.

\section{IV - References}

Mannonov A.M. Roshani literature. -T.: Science, 2006.

Ansari Boyazid.” Khayru 1-bayan.” Manuscript in the library of Tübinberg (Germany). Inventory No. 4093.

Eskerkhanov G.L. The emergence and development of Sufism in the North-Eastern Caucasus. 2011.

Mamatov M.A. Sufism-humanistic trend in Islam. Journal: Humanistic sciences. Bulletin of the Financial University. 2012. HAC.

Al Zhullabi. "Kashfu 1 mahjub" p.36

Ahmadi Zham. Anis at Tolibiyin wa sirot Allah al Mubin, p. 44.

Kerimov G.M. Al Gazzaley and Sufism. Baku. 1969.

Tholuck F.A. Sufismus sive theosophia Persarum pantheistica.

Browne E.Q. Literary history of Persia 6-4. Cambridge / 1951

Hartman R / Zur Froge nach der Hernuff und Aflanding des Sufismus der Islam 6.1916.

Krimsky A. E. An outline of the development of Sufism until the end of the 3rd century Hijri. 1895, p. 47.

Bertels E.E. Sufism and Sufi Literature. Collected works. Moscow, 1965, T-3. p. 35-36.

Anis at Tolibiyin, p. 74.

Pelevin M. S. Afghan poetry in the first half-middle of the XVII century. 2003. HAC.

Ali Mukhlis, Ali Muhammad. Manuscript of the poetry office kept in the British Museum. inv. № 6756.41-p.

Bertels E.E. Sufism and Sufi Literature, Moscow, 1963, p-39.

Nurnoma. Diniy-ma'rifiy pamphlet.

State Formation Afghanistan / Afghanistan. www.hyno.ru/tom-2/

Baranchikov E.V., Maklakov V.V., Voropaev A.I. The Islamic Republic of Afghanistan / Afghanistan. 